\title{
PENGUATAN KARAKTER MANDIRI, DISIPLIN, KERJASAMA DAN KREATIF ("MARIKERJA KREATIF") MELALUI LESSON STUDY PADA PEMBELAJARAN TEKNOLOGI SEPEDA MOTOR
}

\section{STRENGTHENING INDEPENDENT, DISCIPLINE, COOPERATION AND CREATIVE CHARACTERS BY LESSON STUDY IN LEARNING OF MOTORCYCLE TECHNOLOGY}

\author{
Yosep Efendi ${ }^{1}$, Sudarwanto ${ }^{2}$ \\ Program Studi Pendidkan Teknik Otomotif FT UNY \\ Email: yosepefendi@uny.ac.id
}

\begin{abstract}
ABSTRAK
Tujuan penelitian ini adalah untuk mengidentifikasi karakter yang relevan, menguatkan karakter dan mengetahui pengaruh penguatan karakter "MARIKERJA Kreatif" (Mandiri, Disiplin, Kerjasama dan Kreatif) terhadap motivasi kewirausahaan mahasiswa. Penelitian ini dilakukan di Jurusan Pendidikan Teknik Otomotif FT UNY. Metode penelitian dengan lesson studi pendekatan Project Based Learning. Pengumpulan data dilakukan melalui observasi dan data dianalisis menggunakan metode statistik deskriptif. Hasil penelitian ini adalah (1) kompetensi Perawatan dan Perbaikan Sistem Bahan Bakar relevan untuk penguatan karakter mandiri. Karakter Mandiri dikuatkan pada kompetensi sistem pelumasan dan pembuatan laporan praktikum. Karakter kerjasama dikuatkan pada kompetensi mekanisme Katup sedangkan karakter kreatif dikuatkan pada overhaul mesin dan penyusunan rencana bisnis bengkel sepeda motor. (2) Karakter Mandiri, Disiplin, Kerjasama dan Kreatif (MARIKERJA Kreatif) dapat dikuatkan dalam kompetensi Tune Up Sepeda Motor. (3) Lesson study dapat menguatkan karakter kerjasama ( 0,86 poin), kedisiplinan ( 0,75 poin), kemandirian $(0,86$ poin) dan kreatifitas (1,5 poin ). (4) Kegiatan Lesson Studi berbasis penumbuhan karakter dengan tema "MARIKERJA Kreatif' ini dapat menumbuhkan jiwa kewirausahaan mahasiswa.
\end{abstract}

Kata kunci: mandiri, disiplin, kerjasama, kreatif, kewirausahaan

\begin{abstract}
The purpose of this study was to identify relevant characters, strengthen the character and determine the effect of strengthening the character of Independent, Discipline, cooperative and Creative) on student entrepreneurial motivation. This research was conducted in the Department of Automotive Engineering, Unversitas Negeri Yogyakarta. The research method is lesson study with Project Based Learning approach. Data was collected by observation and analyzed using descriptive statistical methods. The results of this study are (1) the competency of Maintenance and Repair of Fuel Systems is relevant for strengthening the independent character. The character of Independent is strengthened in the lubrication system competency and manufacturing practicum reports. The character of cooperation is strengthened in the competence of the Valve mechanism while the creative character is strengthened in the engine overhaul and the preparation of the motorcycle workshop business plan. (2) Character of independent, Discipline, Cooperation and Creative can be strengthened in the competence of Motorbikes Tune Up. (3) Lesson study can strengthen the character of cooperation (0.86 points), discipline (0.75 points), independence (0.86 points) and creativity (1.5 points). (4) Lesson Studies based on character building can foster students' entrepreneurial motivation.
\end{abstract}

Keywords: independent, disciplined, cooperative, creative, entrepreneurship

\section{Pendahuluan}

Universitas Negeri Yogyakarta

(UNY) merupakan salah satu Perguruan

Tinggi yang fokus pada aplikasi dan pengembangan ilmu kependidikan.

Sebagai Lembaga Pendidikan Tenaga Pendidik (LPTK), UNY bertanggungjawab mencetak Pendidik yang berkarakter mulia. Karakter mulia yang nantinya dapat menjadi teladan bagi peserta didik. Oleh sebab itu, UNY selalu mengedepankan prinsip penumbuhan karakter yang kemudian menjadi menjadi slogan UNY, yaitu Leading in Character Education. 
Penumbuhan karakter dapat diterapkan saat pembelajaran. Pembelajaran praktik bengkel yang menjadi ciri khas Jurusan Pendidikan Otomotif khususnya dan Fakultas Teknik pada umumnya merupakan media paling efektif untuk penumbuhan karakter mulia mahasiswa. Mulai dari karakter kemandirian, dimana mahasiswa diminta untuk mencari dan membaca materi pembelajaran sebelum waktu tatap muka perkuliahan. Selain itu, mahasiswa juga diminta untuk rajin mencari informasi terkait perkembangan teknologi otomotif. Sebab, teknologi otomotif berkembang pesat.

Selain karakter kemandirian, karakter disiplin juga ditanamkan, terutama saat masuk kelas/praktik bengkel, dimana ada sanksi bagi yang terlambat. Karakter kerjasama ditumbuhkan melalui pembagian kelompok kerja saat kuliah praktik bengkel otomotif. Karakter tanggungjawab diterapkan melalui tugas dan tanggungjawab menjaga keutuhan alat dan bahan praktik. Karakter kepedulian terhadap rekan mahasiswa dan kepedulian menjaga alat dan bahan praktik. Serta penumbuhan kreatifitas dan inovasi melalui pemberian job-job dan tugas laporan praktikum. Dalam laporan tersebut, mahasiswa diminta untuk menuliskan inovasi kewirausahaan yang dapat diciptakan terkait dengan job praktikum. Selain menumbuhkan sikap kreatif dan inovatif, juga menanamkan jiwa kewirausahaan.

Penumbuhan jika kewirausahaan menjadi suatu komponen penting untuk menghadapi dinamika ekonomi yang meruncing pada bisnis industri kreatif. Dimana dalam bisnis tersebut calon pengusaha/pengusaha dituntut untuk terus kreatif dan menghasilkan inovasi-inovasi yang diterima pasar. Jiwa kewirausahaan ini penting untuk ditumbuhkan mengingat jumlah pengusaha Indonesia pada tahun 2017 masih relatif sedikit, hanya 3,1 \% dari jumlah penduduk. Angka tersebut masih lebih rendah dibandingkan dengan negara lain seperti Malaysia $5 \%$, China 10 $\%$, Singapura $7 \%$, Jepang $11 \%$ dan AS yang $12 \%$ (sumber data: http://www.depkop.go.id). Jurusan Pendidikan Teknik Otomotif berpeluang besar menambah angka tersebut, dibuktikan dengan cukup banyak alumni yang sukses membangun bisnis sendiri, yaitu bisnis di bidang teknologi otomotif. Selain itu, tak sedikit alumni yang menjadi pimpinan perusahaan profit yang menuntut mereka untuk berjiwa wirausaha.

Tingginya peluang alumni Jurusan Pendidikan Teknik Otomotif untuk menjadi pengusaha bidang otomotif dikarenakan jumlah populasi kendaraan terus meningkat setiap tahunnya. Berdasarkan data Badan Pusat Statistik (BPS), diketahui bahwa jumlah kendaraan tahun 2016 mencapai 129.281.079 unit, dengan rata-rata peningkatan $6 \%$ setiap tahun. Populasi kendaraan dalam jumlah besar dan selalu meningkat setiap tahun menjadi peluang wirausaha bagi alumni Pendikan Teknik Otomotif, khususnya di sektor jasa perawatan kendaraan. Oleh sebab itu, menjadi penting untuk menumbuhkan jiwa wirausaha sejak dini kepada mahasiswa, sebagai bekal saat meraka lulus nanti.

Ada beberapa faktor penting pendukung penumbuhan karakter pada mata kuliah TSM. Pertama, mata kuliah TSM berbobot 3 sks, dan ketiga sks tersebut adalah sks praktik (semuanya praktikum) dengan durasi waktu 6 kali 50 menit (300 menit). Dengan durasi waktu pembelajaran yang relatif panjang, akan 
membuat upaya penumbuhan karakter menjadi lebih bermakna dan komprehensif. kedua, sepeda motor adalah jenis kendaraan yang populasinya terbanyak di Indonesia, mencapai 105.150.082 unit pada tahun 2016 dan selalu meningkat setiap tahun. Populasi dalam jumlah besar tersebut menjadi peluang bisnis yang baik bagi alumni Pendidikan Teknik Otomotif.

Faktor ketiga, jurusan Pendidikan Teknik Otomotif memiliki bengkel sepeda motor yang dikelola mahasiswa, yaitu Bengkel Automotive Training Center (ATC). Bengkel tersebut menerima jasa perawatan sepeda motor masyarakat dan sudah memiliki cukup banyak pelanggan. Bengkel tersebut bisa menjadi inkubator bisnis bagi mahasiswa dan memberikan pengalaman nyata berwirausaha pada mahasiswa. Setiap tahun, bengkel tersebut menerima seleksi mekanik dari kalangan mahasiswa. Namun, faktanya hanya sebagian kecil mahasiswa yang berminat untuk mengikuti seleksi tersebut.

Tujuan utama penelitian ini adalah untuk mengidentifikasi karakter yang relevan, menguatkan karakter dan mengetahui pengaruh penguatan karakter "MARIKERJA Kreatif" (Mandiri, Disiplin, Kerjasama dan Kreatif) terhadap motivasi kewirausahaan mahasiswa.

Konsep "MARIKERJA Kreatif” (Mandiri, Disiplin, Kerjasama dan Kreatif)

$\begin{array}{cccr}\quad \text { Dalam } & \text { Kamus } & \text { Besar } & \text { Bahasa } \\ \text { Indonesia } & \text { Daring, } & \text { mandiri } & \text { dan } \\ \text { kemandirian } & \text { diartikan } & \text { sebagai } & \text { dalam }\end{array}$
keadaan dapat berdiri sendiri dan tidak bergantung pada orang lain. Menurut Steinberg (dalam Patriana, 2007 : 20) kemandirian diri adalah kemampuan individu untuk bertingkah laku seorang diri. Lebih lanjut lagi, Steinberg menjabarkan aspek kemandirian yang melibatkan 3 hal, yaitu emotional autonomy, behavioral autonomy dan value autonomy.

Aspek emotional autonomy berkaitan dengan perubahan hubungan individu khususnya orangtua, yang dibentuk dalam lingkungan keluarga. Aspek behavioral autonomy berkaitan dengan kemampuan untuk membuat keputusan sendiri dan menjalankan keputusan tersebut, yang dibangun dalam diri pribadi. Sedangkan aspek value autonomy berkaitan dengan seperangkat prinsip-prinsip yang berhubungan dengan benar dan salah serta hal penting dan tidak penting. Ketiga aspek tersebut saling berkaitan dan secara bersama-sama membentuk jiwa kemandirian individu.

Kemandirian dapat dibentuk dan dikembangkan dengan berbagai upaya. Menurut Ali dan Asrori (2008 : 118), sistem pendidikan di sekolah dapat mendukung pembentukan kemandirian jika sistem pendidikan menekankan pentingnya penghargaan terhadap potensi anak, pemberian reward serta penciptaan kompetisi positif. Maka dengan perhargaan terhadap potensi dan dengan memberikan ruang kompetisi yang sehat, akan menumbuhkan karakter kemandirian.

Karakter selanjutnya adalah disiplin. Dalam dunia pendidikan, disiplin merupakan salah satu sikap yang terus digaungkan dan dibentuk sejak awal. Dalam KBBI Daring, disiplin diartikan sebagai ketaatan (kepatuhan) kepada peraturan (tata tertib dan sebagainya). Menurut Masykur (2011:64) disiplin berasal dari bahasa Inggris "discipline" yang mengandung beberapa arti, pengendalian diri, membentuk karakter yang bermoral, memperbaiki dengan sanksi, serta kumpulan beberapa tata tertib untuk mengatur tingkah laku. 
Menurut Moenir (2010:95-96), disiplin ada dua jenis, yaitu disiplin waktu dan disiplin perbuatan. Menurutnya, kedua jenis disiplin tersebut merupakan kesatuan yang tidak dapat dipisahkan serta saling mempengaruhi. Bisa saja seseorang hadir tepat waktunya, tetapi tidak segera melakukan perbuatan sesuai ketentuan organisasi pada hakekatnya merugikan organisasi. Berdasarkan penjelasan para ahli tersebut, dapat disimpulkan bahwa disiplin merupakan sikap mengendalikan diri untuk mentaati peraturan, yang dapat dicerminkan dari menghargai waktu dan menjaga perbuatan sesuai peraturan.

Karakter mandiri dan disiplin memang tampak sebagai sikap internal individu, namun jika diperhatikan lebih mendalam, sikap tersebut dapat dipengaruhi oleh faktor eksternal. Terlebih, manusia adalah makhluk sosial yang butuh bersosialisasi dan bermasyarakat serta saling membutuhkan. Oleh sebab itu, manusia butuh kerjasama. Kerjasama bukan berbarti manusia tidak dapat mandiri, sebab manusia memiliki keterbatasan kamampuan. Dengan kerjasama, keterbatasan tersebut dapat diisi oleh kemapuan orang lain dan berorganisasi untuk mencapai tujuan. Sebagaimana yang diutarakan oleh Soerjono Soekanto (2006: 66), bahwa kerjasama merupakan suatu usaha bersama antara orang perorangan atau kelompok untuk mencapai tujuan tertentu. Definisi tersebut dapat dimaknai bahwa tiap individu atau kelompok dapat berinteraksi untuk mencapai tujuan bersama.

Karakter selanjutnya yang saat ini menjadi tuntutan generasi milenial adalah kreatif. Dalam KBBI, kreatif diartikan sebagai memiliki daya cipta; memiliki kemampuan untuk menciptakan; bersifat (mengandung) daya cipta. Lebih jelas lagi,
Subali (2014: 507) menyatakan bahwa kemapuan berfikir kreatif merupakan upaya berpikir dan melakukan sesuatu untuk menghasilkan cara atau hasil baru dari sesuatu yang telah dimiliki. Pendapat tersebut dapat dimaknai bahwa kreatif adalah mampu menghasilkan cara atau metode baru.

Hubungan "MARIKERJA Kreatif", Pendidikan Kejuruan dan Kewirausahaan

Dalam naskah "Pengembangan Pendidikan Budaya dan Karakter Bangsa" yang disusun oleh Kementerian Pendidikan Nasional, nilai-nilai pendidikan karakter yang dapat diimplementasikan dalam penumbuhan jiwa kewirausahaan nilainilai kewirausahaan adalah : (1) mandiri, (2) kreatif, (3) berani mengambil resiko dengan pertimbangan, (4) berorientasi pada tindakan, (5) kepemimpinan, (6) kerja keras, (7) Jujur, (8) Disiplin, (9) Inovatif, (10) Tanggung-jawab, (11) Kerja sama , (12) Pantang menyerah (ulet), Komitmen, (14) Realistis, (15) Rasa ingin tahu, (16) Komunikatif, (17) Motivasi kuat untuk sukses (Kemendiknas: 2010, 10). Empat dari 17 karakter tesebut yang akan diimlementasikan pada matakuliah Teknologi Sepeda Motor, yaitu mandiri, disiplin, kerjasama dan kreatif, yang kemudian dibuat dalam suatu konsep yaitu MARIKERJA Kreatif.

Dalam pendidikan kejuruan, dikenal istilah life skill atau kecakapan hidup. Pendidikan kejuruan bertujuan untuk memberikan keterampilan khusus kepada peserta didik, dimana keterampilan tersebut dapat dimanfaatkan untuk bekerja di industri atau mandiri membangun usaha sendiri. Kemandirian berbekal keterampilan kejuruan tersebut merupakan aplikasi dari life skill atau kecakapan hidup. Sebagaimana Menurut Brolin 
(1980) dalam Jamal (2009, 29-30), life skill atau kecakapan hidup adalah kontinum pengetahuan dan kemampuan yang diperlukan oleh seseorang agar menjadi independen dalam kehidupan. Independen tersebut sangat relevan dengan poin pertama pada konsep "MARIKERJA Kreatif", yaitu mandiri. Dengan bekal keterampilan kejuruan dan sikap mandiri, maka sesorang bisa berwirausaha, khususnya wirausaha yang sesuai dengan bidang keahlian kejuruan.

\section{Metode Penelitian}

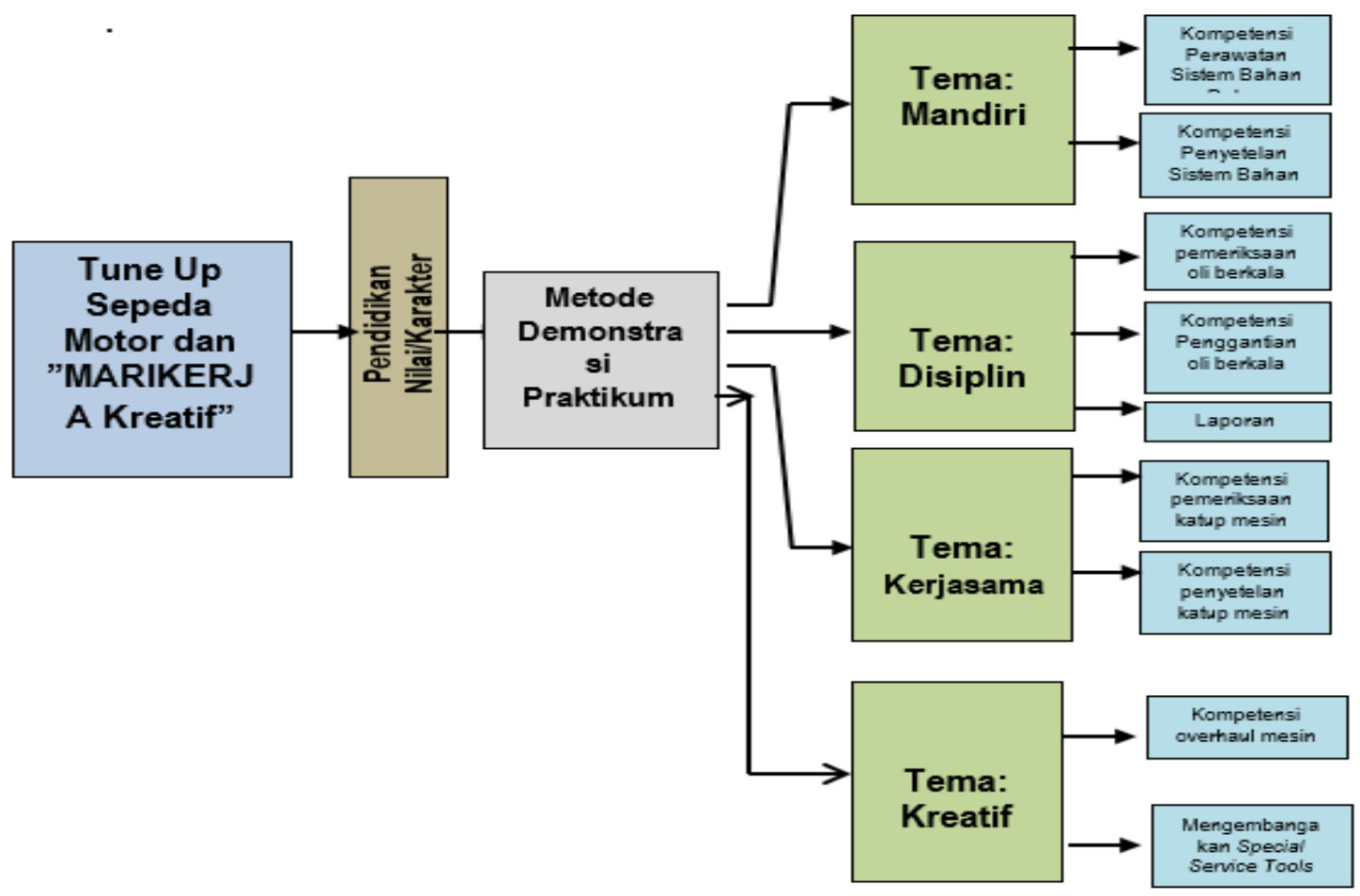

Gambar 1. Pengintegrasian Konsep Karakter "MARIKERJA Kreatif" melalui metode Project-Based Learning pada mata kuliah Teknologi Sepeda Motor

Dalam dalam kegiatan Lesson Study ini diperoleh berdasarkan observasi yang dilakukan oleh 2 orang dosen observer. Instrumen pengumpulan data menggunakan lembar observasi.
Kegiatan implementasi konsep karakter "MARIKERJA Kreatif" ini dilakukan dengan strategi Lesson Study. Lesson study yang akan dilaksanakan menggunakan pendekatan Project Based Learning, dengan strategi tindakan/treatment disesuaikan dengan kondisi kelas dan akan dilakukan 3 siklus tindakan yaitu Pra-Tindakan, Tindakan 1 dan Tindakan 2. Berikut ini rancangan integrasi konsep karakter "MARIKERJA Kreatif" melalui metode Lesson Study pada mata kuliah Teknologi Sepeda Motor. 
Sepeda Motor (TSM) merupakan mata kuliah praktik tentang berbagai sistem dan teknologi pada sepeda motor. Mata kuliah TSM dengan kode OTO 6350 memiliki bobot 3 sks praktikum dengan durasi waktu pembelajaran tatap muka 6 x 50 menit (300 menit).

Berdasarkan observasi saat perkuliahan praktik Teknologi Sepeda Motor, ada beberapa fenomena menarik yang penting untuk dikaji. Pertama, saat softtalk di awal perkuliahan (sebelum mulai praktik), ada beberapa mahasiswa yang belum menyiapkan materi atau tidak membaca materi sebelum perkuliahan praktik. Padahal, materi teoritis sangat mendukung dalam kegiatan praktik, agar praktik lebih terarah.

Kedua, durasi perkuliahan yang relatif lama (6 x 50 menit), cenderung membuat mahasiswa letih dan jenu. Kondisi tersebut membuat mahasiswa tampak letih dan kurang semangat terutama saat pertengahan akhir perkuliahan. Hal itu salah satunya ditandai dengan kurang fokusnya mahasiswa dalam mengerjakan job yang telah diinstruksikan. Selain itu, beberapa mahasiswa kerap izin meninggalkan bengkel sesaat, dengan berbagai alasan, akibat dari kejenuhan. Dengan kerapnya mahasiswa izin meninggalkan sesaat bengkel, membuat pembagian kerja dalam kelompok menjadi tidak terarah dan mahasiswa cenderung menjadi individualis. Padahal, dalam pembelajaran TSM, diutamakan kerjasama kelompok untuk mencapai penguasaan kompetensi individu. Artinya, secara bersama-sama mereka melakukan pekerjaan Tune Up Sepeda Motor dan kemudian setiap kompetensi dan permasalahan pada Tune Up Sepeda Motor dibahas dalam satu kelompok.

Setelah pembahanan kelompok, setiap mahasiswa dituntut untuk praktik individu, untuk membentuk kemandirian kerja dan tanggungjawab individu. Jika dalam satu kelompok tidak terjadi diskusi dan kerjasama, maka akan mengalami kesulitan saat melakukan job individu. Oleh sebab itu, memang penting untuk lebih menguatkan karakter kerjasama dan kemandirian dalam diri mahasiswa, khususnya melalui penerapan karakter dalam perkuliahan TSM.

Selain itu, fenomena lain yang penting untuk dikaji adalah rendahnya kreatifitas mahasiswa, terutama dalam penggunaan alat dan proses kerja. Dalam semua jenis pekerjaan perawatan dan perbaikan sepeda motor, memang sudah ada Standard Operational Procedure (SOP) dan Manual Book yang menjadi pedoman mekanik. Namun, ada kalanya dalam kondisi mendesak, mekanik harus menggunakan peralatan seadanya yang kemudian berdampak pada proses kerja yang tidak sesuai SOP. Oleh sebab itu, mahasiswa perlu dilatih untuk kondisi darurat dan keterbatasan alat, yang diharapkan dapat menumbuh-kembangkan kreatifitas mereka.

\section{Hasil Implementasi Lesson Studi "MARIKERJA Kreatif"}

Observer telah mengamati perkuliahan selama 3 kali pertemuan (3 praktikum). Hasil pengamatan dari observer dicatat pada lembar observasi. Berikut ini adalah tabulasi hasil pengamatan observer untuk semua karakter yang dikuatkan pada perkuliahan: 
Tabel 1. Skor Rata-Rata Penilaian Observer Pada Pelaksanaan Lesson Study

\begin{tabular}{|c|c|c|c|c|}
\hline \multirow[t]{2}{*}{ No } & \multirow[t]{2}{*}{ Butir Yang Diamati } & \multicolumn{3}{|c|}{ Skor Observasi Kelas } \\
\hline & & Pra & $\begin{array}{c}\text { Siklus } \\
1\end{array}$ & $\begin{array}{l}\text { Siklus } \\
2\end{array}$ \\
\hline 1 & Kehadiran mahasiswa dalam perkuliahan & 5 & 5 & 4 \\
\hline 2 & Hadir kuliah tepat waktu & 4 & 5 & 4 \\
\hline 3 & $\begin{array}{l}\text { Kesiapan materi teoritis (materi pendukung praktik) } \\
\text { mahasiswa sebelum mengikuti perkuliahan praktik }\end{array}$ & 2,5 & 3 & 3,5 \\
\hline 4 & Mahasiswa merespon tugas yang diberikan & 3,5 & 3 & 3,5 \\
\hline 5 & Mahasiswa merespon tugas (job) individu di bengkel & 3,5 & 4 & 3,5 \\
\hline 6 & $\begin{array}{l}\text { Ketepatan waktu dalam menyelesaikan tugas (job) individu } \\
\text { di bengkel }\end{array}$ & 3,5 & 3 & 5 \\
\hline 7 & Interaksi antara mahasiswa dan dosen & 3 & 4 & 4,5 \\
\hline 8 & $\begin{array}{l}\text { Bahan belajar (buku/modul/ebook/dsb) yang dibawa oleh } \\
\text { mahasiswa saat praktik }\end{array}$ & 2,5 & 3 & 3,5 \\
\hline 9 & Intensitas mahasiswa mengakses Manual Book & 2,5 & 3,5 & 4 \\
\hline 10 & $\begin{array}{l}\text { Interaksi antara mahasiswa dan media/sumber belajar/job } \\
\text { sheet }\end{array}$ & 2,5 & 3 & 3,5 \\
\hline 11 & Mahasiswa membangun kerja tim dalam satu kelompoknya & 3,5 & 4 & 4 \\
\hline 12 & $\begin{array}{l}\text { Interaksi antara mahasiswa dan media/sumber belajar/job } \\
\text { sheet }\end{array}$ & 3 & 3 & 4,5 \\
\hline 13 & Keaktifan mahasiswa dalam kelompok praktikum & 3,5 & 4 & 4,5 \\
\hline 14 & Kemampuan diskusi mahasiswa dalam satu kelompoknya & 4 & 4 & 4 \\
\hline 15 & Pembagian tugas mahasiswa dalam kelompoknya & 3 & 3,5 & 4,5 \\
\hline 16 & Kemampuan mahasiswa dalam penguasaan training object & 3 & 3,5 & 3,5 \\
\hline 17 & Keaktifan mahasiswa dalam perkuliahan & 3 & 3,5 & 4,5 \\
\hline 18 & Mahasiswa merespon tugas kelompok yang diberikan & 3,5 & 4 & 4,5 \\
\hline 19 & Ketepatan penggunaan alat praktikum & 3 & 3,5 & 4 \\
\hline 20 & Pengembalian alat pada tempatnya & 3,5 & 4 & 5 \\
\hline 21 & Mahasiswa kreatif dalam merespon keterbatasan alat & 2,5 & 3 & 4,5 \\
\hline 22 & Mahasiswa menggunakan SST & 3 & 3,5 & 4 \\
\hline 23 & $\begin{array}{l}\text { Mahasiswa menyusun Strategi marketing pada simulasi } \\
\text { bisnis sepeda motor }\end{array}$ & 3 & 3 & 4,5 \\
\hline 24 & $\begin{array}{l}\text { Mahasiswa menyusun strategi promosi pada simulasi bisnis } \\
\text { sepeda motor }\end{array}$ & 2,5 & 3 & 4 \\
\hline
\end{tabular}

Skor Rata-rata $\quad 3,19 \quad 3,58 \quad 4,12$

\section{Rentang Skor :}
5 : Sangat Baik
4: Baik 3 : Cukup
2 : Kurang
Sangat
Kurang

Berdasarkan tabel 1 di atas, diketahui bahwa terjadi peningkatan kualitas pembelajaran selama pelaksanaan tindakan lesson study. Pada tahapan pratindakan, skor observasi kualitas pembelajaran hanya 3,19 (cukup). Setelah dilakukan perbaikan strategi pembelajaran berdasarkan hasil evaluasi (see), maka kualitas pembelajaran mulai mengalami peningkatan, angka 3,58. Meskipun masih termasuk kategori cukup, tetapi mengalami sedikit peningkatan. Pada pelaksanaan tindakan 2 skoring yang dilakukan observer terhadap proses pembelajaran ternyata meningkat, yaitu pada skor 4,12 (kategori baik). Sedangkan skor hasil observasi berdasarkan karakter yang 
dikuatkan tercantum pada tabel 2 di bawah ini:

Tabel 2. Skor Observasi Berdasarkan Nilai Karakter Yang Dikuatkan

\begin{tabular}{|c|c|c|c|c|}
\hline \multirow[b]{2}{*}{ No } & \multirow[b]{2}{*}{ Butir Yang Diamati } & \multicolumn{3}{|c|}{ Skor Observasi Kelas } \\
\hline & & Pra & Siklus 1 & Siklus 2 \\
\hline \multicolumn{5}{|c|}{ Karakter Mandiri } \\
\hline 1 & $\begin{array}{l}\text { Kesiapan materi teoritis (materi pendukung } \\
\text { praktik) mahasiswa sebelum mengikuti } \\
\text { perkuliahan praktik }\end{array}$ & 2,5 & 3 & 3,5 \\
\hline 2 & Mahasiswa merespon tugas yang diberikan & 3,5 & 3 & 3,5 \\
\hline 3 & $\begin{array}{l}\text { Mahasiswa merespon tugas (job) individu di } \\
\text { bengkel }\end{array}$ & 3,5 & 4 & 3,5 \\
\hline 4 & $\begin{array}{l}\text { Bahan belajar (buku/modul/ebook/dsb) yang } \\
\text { dibawa oleh mahasiswa saat praktik }\end{array}$ & 2,5 & 3 & 3,5 \\
\hline 5 & $\begin{array}{l}\text { Interaksi antara mahasiswa dan } \\
\text { media/sumber belajar/job sheet }\end{array}$ & 3 & 3 & 4,5 \\
\hline 6 & $\begin{array}{l}\text { Interaksi antara mahasiswa dan } \\
\text { media/sumber belajar/job sheet }\end{array}$ & 2,5 & 3 & 3,5 \\
\hline \multirow[t]{3}{*}{7} & $\begin{array}{l}\text { Intensitas mahasiswa mengakses Manual } \\
\text { Book }\end{array}$ & 2,5 & 3,5 & 4 \\
\hline & Skor Rata-rata Mandiri & 2,86 & 3,21 & 3,71 \\
\hline & Karakter Disiplin & & & \\
\hline 1 & Kehadiran mahasiswa dalam perkuliahan & 5 & 5 & 4 \\
\hline 2 & Hadir kuliah tepat waktu & 4 & 5 & 4 \\
\hline 3 & $\begin{array}{l}\text { Ketepatan waktu dalam menyelesaikan tugas } \\
\text { (job) individu di bengkel }\end{array}$ & 3,5 & 3 & 5 \\
\hline 4 & Keaktifan mahasiswa dalam perkuliahan & 3 & 3,5 & 4,5 \\
\hline 5 & Ketepatan penggunaan alat praktikum & 3 & 3,5 & 4 \\
\hline \multirow[t]{3}{*}{6} & Pengembalian alat pada tempatnya & 3,5 & 4 & 5 \\
\hline & Skor Rata-rata Disiplin & 3,67 & 4,00 & 4,42 \\
\hline & Karakter Kerjasama & & & \\
\hline 1 & Interaksi antara mahasiswa dan dosen & 3 & 4 & 4,5 \\
\hline 2 & $\begin{array}{l}\text { Mahasiswa membangun kerja tim dalam satu } \\
\text { kelompoknya }\end{array}$ & 3,5 & 4 & 4 \\
\hline 3 & $\begin{array}{l}\text { Keaktifan mahasiswa dalam kelompok } \\
\text { praktikum }\end{array}$ & 3,5 & 4 & 4,5 \\
\hline 4 & $\begin{array}{l}\text { Kemampuan diskusi mahasiswa dalam satu } \\
\text { kelompoknya }\end{array}$ & 4 & 4 & 4 \\
\hline 5 & $\begin{array}{l}\text { Pembagian tugas mahasiswa dalam } \\
\text { kelompoknya }\end{array}$ & 3 & 3,5 & 4,5 \\
\hline
\end{tabular}




\begin{tabular}{cllcc}
\hline \multirow{2}{*}{ No } & \multicolumn{1}{c}{ Butir Yang Diamati } & \multicolumn{3}{c}{ Skor Observasi Kelas } \\
\cline { 3 - 5 } & Pra & Siklus 1 & Siklus 2 \\
\hline $\mathbf{6}$ & $\begin{array}{l}\text { Kemampuan mahasiswa dalam penguasaan } \\
\text { training object }\end{array}$ & 3 & 3,5 & 3,5 \\
\hline 7 & $\begin{array}{l}\text { Mahasiswa merespon tugas kelompok yang } \\
\text { diberikan }\end{array}$ & 3,5 & 4 & 4,5 \\
\hline
\end{tabular}

\begin{tabular}{llccc}
\hline \multicolumn{1}{c}{ Skor Rata-rata Kerjasama } & $\mathbf{3 , 3 6}$ & $\mathbf{3 , 8 6}$ & $\mathbf{4 , 2 1}$ \\
\hline \multicolumn{1}{c}{ Karakter Kreatif } & 2,5 & 3 & 4,5 \\
\hline $\mathbf{1}$ & $\begin{array}{l}\text { Mahasiswa kreatif dalam merespon } \\
\text { keterbatasan alat }\end{array}$ & 3 & 3,5 & 4 \\
\hline $\mathbf{2}$ & Mahasiswa menggunakan SST & 3 & 3 & 4,5 \\
\hline $\mathbf{3}$ & $\begin{array}{l}\text { Mahasiswa menyusun Strategi marketing } \\
\text { pada simulasi bisnis sepeda motor }\end{array}$ & 2,5 & 3 & 4 \\
\hline $\mathbf{4}$ & $\begin{array}{l}\text { Mahasiswa menyusun strategi promosi pada } \\
\text { simulasi bisnis sepeda motor }\end{array}$ & & & \\
\hline
\end{tabular}

Skor Rata-rata Kreatif $\quad 2,75 \quad 3,125 \quad 4,25$

Berdasarkan tabel 2 di atas, mulai dari pra tindakan, siklus 1 hingga diketahui bahwa pada tiap aspek karakter siklus 2 . (mandiri, disiplin, kerjasama dan kreatif) mengalami peningkatan mulai dari tindakan pra tindakan hingga tindakan kedua. Karakter disiplin mengalami peningkatan 0,75 poin. Karakter mandiri dan kerjasama mengalami peningkatan poin yang sama, yaitu 0,86 . Sedangkan karakter kreatif mengalami peningkatan tertinggi, yaitu 1,5 poin.

\section{Pembahasan}

Berdasarkan hasil skoring pada tabel 1, dapat dilihat bahwa terjadi peningkatan kualitas proses pembelajaran, mulai dari pra-tindakan, tindakan 1 (siklus 1) hingga tindakan 2 (siklus 2). Selain Peningkatan secara umum (skor rata-rata keseluruhan), juga terjadi peningkatan kualitas penumbuhan karakter pada 4 aspek karakter yang ditanamkan pada kegiatan ini, yaitu mandiri, disiplin, kerjasama dan kreatif. Skoring keempat karakter tersebut secara umum meningkat
Berbagai peningkatan tersebut disebabkan karena pada setiap awal pembelajaran, mahasiswa diberi pemahaman tentang pentingnya karakter mandiri, disiplin, kerjasama dan kreatif dalam menunjang kesuksesan proses pembelajaran. Dengan demikian, mahasiswa akan berusaha untuk mengaplikasikan karakter tersebut dalam proses pembelajaran yang kemudian penerapan tersebut tercatat oleh observer yang mengamati proses pembelajaran mulai dari awal hingga akhir.

Berdasarkan hasil obeservasi, karakter kreatif mengalami penguatan tertinggi diantara 3 karakter lainnya, yaitu meningkat 1,5 poin. Hal tersebut dapat terjadi didasari oleh peningkatan kompetensi mahasiswa. Ketika mahasiswa telah cukup kompeten dalam menyelesaikan job yang menjadi tugasnya, maka kreatifitas akan berkembang. Hal 
tersebut didukung oleh kuatnya karakter kedisiplinan, kemandirian dan terutama kerjasama. Sikap kerjasama telah membentuk kebiasaan interaksi dan diskusi yang baik antar mahasiswa. Hal tersebut berdampak pada berkembangnya pola pikir mahasiswa yang selanjutnya dapat mengembangkan kreatifitas mahasiswa.

Meskipun secara umum telah terjadi peningkatan kualitas proses pembelajaran, namun ada beberapa catatan penting yang harus diperhatikan. Pertama, terjadi penurunan jumlah mahasiswa yang merespon tugas yang diberikan oleh dosen model (instrumen nomer 5) yaitu pada tindakan 1 dan tindakan 2, dari skor 4 menjadi 3,5. Hal ini dapat disebabkan oleh adanya mahasiswa yang belum menguasai kompetensi dan cenderung menunggu dan mengamati mahasiswa lain mengerjakan. Artinya, Ia butuh waktu tambahan untuk belajar dengan mahasiwa lain, melalui proses pengamatan.

Fenomena kedua yang layak mendapat perhatian lebih adalah pada tindakan 2, yaitu masih adanya aspek penilaian yang masuk pada kategori cukup. Aspek tersebut adalah butir instrumen nomer 3, 4, 5, 8, 10 dan 16. Artinya, masih perlu penguatan pada aspek kemandirian mahasiswa dalam mencari materi ajar, ketersediaan bahan ajar oleh mahasiswa, interaksi atau akses mahasiswa terhadap sumber belajar, respon tugas dan kemapuan mahasiswa dalam menguasai training objek. Dari fenomena tersebut maka perlu perlakuan lebih pada aspek literasi mahasiswa, akan mahasiswa lebih sadar pentingnya mengumpulkan dan mengakses sumber belajar.

\section{KESIMPULAN}

Berdasarkan kegiatan Lesson Study yang telah dilakukan, diperoleh kesimpulan bahwa:

1. Kompetensi Perawatan dan

Perbaikan Sistem Bahan Bakar relevan untuk penguatan karakter mandiri. Karakter Mandiri dikuatkan pada kompetensi sistem pelumasan (oli) dan pembuatan laporan praktikum. Karakter kerjasama dikuatkan pada kompetensi mekanisme Katup sedangkan karakter kreatif dikuatkan pada overhaul mesin, penggunaan SST dan penyusunan rencana bisnis bengkel sepeda motor.

2. Karakter Mandiri, Disiplin, Kerjasama dan Kreatif (MARIKERJA Kreatif) dapat dikuatkan dalam kompetensi Tune Up Sepeda Motor.

3. Kegiatan penumbuhan karakter melalui Lesson Study yang yang telah dilaksanakan berdampak baik terhadap kualitas proses pembelajaran Teknologi Sepeda Motor. Selain itu, lesson study juga dapat menguatkan karakter kerjasama, kedisiplinan, kemandirian dan kreatifitas mahasiswa ditandai dengan peningkatan skor observasi pada semua karakter tersebut. Di mana karakter disiplin mengalami peningkatan 0,75 poin, mandiri dan kerjasama mengalami peningkatan poin yang sama, yaitu 0,86 , sedangkan karakter kreatif mengalami peningkatan tertinggi, yaitu 1,5 poin.

4. Kegiatan Lesson Studi berbasis penumbuhan karakter dengan tema "MARIKERJA Kreatif" ini dapat 
menumbuhkan jiwa kewirausahaan mahasiswa, ditandai dengan penyusunan perencanaan bisnis bengkel sepeda motor.

\section{Saran}

Berdasarkan hasil yang diperoleh dari pelaksanaan lesson study, yang menunjukkan arah perbaikan dan peningkatan kualitas proses pembelajaran, maka kegiatan ini layak untuk dilakukan secara kontinyu, khususnya pada semua kompetensi dimata kuliah Teknologi Sepeda Motor dan layak diterapkan pada setiap mata kuliah lainnya. Namun, disisi lain perlunya alokasi waktu yang lebih memadai, sehingga pelaksanaan lesson study dapat berlangsung lebih maksimal. Khususnya alokasi waktu beberapa observer yang akan dilibatkan dalam kegiatan lesson studi.

\section{DAFTAR PUSTAKA}

Badan Pusat Statistik. 2016. Perkembangan Jumlah Kendaraan Bermotor Menurut Jenis. Diakses dari

https://www.bps.go.id/dynamictable/ 2016/02/09/1133/perkembanganjumlah-kendaraan-bermotormenurut-jenis-1949-2016.html.

Departemen Koperasi. 2017. Rasio Wirausaha Indonesia. Diakses dari http://www.depkop.go.id/content/rea d/ratio-wirausaha-indonesia-naikjadi-31-persen/.

Jamal Ma'ruf Asmani. 2009. Sekolah Life Skills, Lulus Siap Kerja. Yogyakarta: Diva Press.

Kementerian Pendidikan Nasional.2010. Pengembangan Pendidikan Budaya dan Karakter Bangsa.Bahan
Pelatihan Penguatan

MetodologiPembelajaran

Berdasarkan Nilai-Nilai Budaya untuk Membentuk DayaSaing dan Karakter Bangsa. Jakarta: Badan Penelitian dan Pengembangan Pusat Kurikulum

Maman Suryaman (Ed). 2014. Memantapkan Pendidikan Karakter Untuk Melahirkan Insan Bermoral, Humanis dan Profesional. Yogyakarta: UNY Press

Masykur Arif Rahman. 2011. Pentingnya Disiplin Belajar. Jakarta : Rineka Cipta.

Moenir. 2010. Masalah-Masalah dalam Belajar. Yogyakarta : Pustaka Pelajar Muhamad Ali dan Muhamad Asrori. (2006). Psikologi Remaja Perkembangan Peserta Didik. Jakarta: Bumi Aksara.

Mulyasa, E. 2009. Implementasi Kurikulunm Tingkat Satuan Pendidikan Kemandirian Guru dan Kepala Sekolah. Jakarta: Bumi Aksara

Pradnya Patriana. (2007). Hubungan antara Kemandirian Diri dengan Motivasi Bekerja sebagai Pengajar Les Privat pada Mahasiswa di Semarang. Skripsi. Fakultas Psikologi UNDIP. Soerjono Soekanto. 2006. Sosiologi Suatu Pengantar, PT. Raja Grafindo Persada, Jakarta 